\title{
The Redesign STRATEgy At Region General Hospital TyPe B In Magelang City
}

\section{Strategi Perancangan Pada Redesain Rumah Sakit Umum DaErah Tidar TiPe B Di Kota Magelang}

\author{
Prananda Fadhlul Husna ${ }^{1 *}$, Sri Yuliani ${ }^{2}$, Ahmad Farkhan ${ }^{3}$ \\ Program Studi Arsitektur, Fakultas Teknik, Universitas Sebelas Maret ${ }^{1 *}$ \\ Email: pranandafh@gmail.com* \\ Program Studi Arsitektur, Fakultas Teknik, Universitas Sebelas Maret ${ }^{2}$ \\ Program Studi Arsitektur, Fakultas Teknik, Universitas Sebelas Maret ${ }^{3}$
}

\begin{abstract}
Health is the prosperous state of the body, soul and social that must always be maintained by way of periodic checks to the hospital. The hospital is health care institutions that provides patient care with medical personsl, specialized nurses and medical equipments that need to be accredited to improve public services. The purpose of this redesain strategy is to formulate the concept of planning and design of Tidar Hospital of Magelang City that meet the criteria of the future. Redesign of RSUD Tidar in Magelang was conducted based on Hospital Building Technical Guidelines in 2012. The research method is divided into three levels, programming, planning and design. Based on the results of the analysis study in field, the redesign has been obtained from the application of the Hospital Building Technical Guidelines. It should be designed on the outpatient installation can make the waiting area wider and the circulation of patients with the officers can be separated. The parking area is placed on the basement area so it is wider. For Emergency Installation is placed close to the main door so that the patient can go directly to this area and the circulation separate from the syringe to the inpatient and service area. Most of room programmes are designed based on universal accessibity.
\end{abstract}

Keywords: redesign, hospital type b, Magelang

\section{PENDAHULUAN}

Rumah Sakit Umum Daerah Tidar Tipe B merupakan institusi yang memberikan pelayanan kesehatan dan penyediaan pelayanan rawat inap, rawat jalan, dan gawat darurat. Dalam rangka peningkatan kualitas perlu adanya standarisasi pengakuan terhadap rumah sakit yang dilakukan oleh Lembaga independen penyelenggara akreditasi yang ditetapkan oleh kementrian. Rumah Sakit Umum Daerah Tidar Kota Magelang telah melakukan akreditasi dengan memperoleh predikat bintang lima. Sertifikat Akreditasi Ruamh Sakit Umum Daerah Tidar Kota Magelang menurut Komisi
Akreditasi Rumah Sakit nomor KARSSERT/647/III/2017 mendapat Paripurna (bintang 5) hingga 27 Februari 2020.

Rumah Sakit Umum Daerah Tidar Kota Magelang yang mempunyai misi "RSUD Tidar Magelang menempatkan diri sebagai RSUD rujukan yang memberikan pelayanan profesional sebagai manifestasi pengabdiannya kepada masyarakat". Dengan misi tersebut diharapkan RSUD Tidar dapat memberikan pelayanan yang profesional dari tahun ke tahun. Maka upaya yang dilakukan oleh RSUD Tidar Kota Magelang untuk memberikan pelayanan prima terhadap pasien dapat terwujud, sehingga 
tujuan untuk mendapatkan jumlah kunjungan pasien dapat sesuai dengan yang diharapkan dari pihak manajemen rumah sakit.

Kondisi saat ini di RSUD Tidar Kota Magelang adalah RSUD bertipe B jika dikaitkan dengan standar Pedoman Teknis Rumah Sakit tahun 2012 masih banyak permasalahan yang terjadi di RSUD Tidar Kota Magelang, seperti area Instalasi Rawat Jalan yang sebaiknya sirkulasi antara pasien dan petugas RS dipisahkan. Demikian pula untuk area masuk UGD harus memiliki pintu masuk yang berbeda dengan kendaraan ke area Instalasi Rawat Jalan/poli, Instalasi Rawat Inap, serta zona service dari Rumah sakit, walaupun bisa dijadikan satu dengan pintu masuk IGD, kemudian jalur yang membedakan area IGD dan instalasi yang lain ditambah dengan area masuk yang seharusnya terbebas dari kendaraan lain (seperti becak dan sepeda), letak IGD harus berdekatan dengan bank darah rumah sakit agar efektif dalam perawatan pasien, kemudian di area parkir yang idealnya adalah $1,5 \mathrm{~s} / \mathrm{d} 2$ kendaraan/ tempat parkir atau sebesar $37,5 \mathrm{~s} / \mathrm{d} 50 \mathrm{~m}^{2}$ per tempat tidur, namun hanya tersedia \pm 50 untuk kendaraan roda 4 atau dengan luasan sekitar $1250 \mathrm{~m}^{2}$. Dan belum tersedianya toilet bagi penyandang disabilitas. Permasalahanpermasalahan yang terjadi di Rumah Sakit Umum Daerah Tidar Kota Magelang ini mengacu pada Peraturan Pemerintah yang dituangkan dalam Pedoman Teknis Bangunan Rumah Sakit Kelas B.

Keadaan yang tidak nyaman ini dapat membuat pasien atau user di dalam rumah sakit menjadi stres. Stres yang terjadi pada pasien dapat menekan sistem imun sehingga mengakibatkan pasien memerlukan waktu perawatan yang lebih lama dan bahkan dapat mempercepat terjadinya komplikasi penyakit selama perawatan (Dani, 2004 dalam Haryndia, 2011: 125).

Bangunan gedung menurut undang-undang nomor 28 tahun 2002 juga menyebutkan bahwa bangunan gedung penting sebagai tempat manusia melakukan kegiatan, maka perlu diperhatikan keamanan, keselamatan, kesehatan, kenyamanan dan kemudahan. Maka, perlu adanya peningkatan pelayanan yang sesuai dengan Pedoman Teknis Bangunan Ruamh Sakit Kelas B tahun 2012.
Salah satu cara meningkatan pelayanan dan mengurangi rasa stress adalah dengan melakukan redesain. Menurut John. M. Echols dan Hasan Shadily Kamus Inggris Indonesia, PT. Gramedia Jakarta, 1990 redesain adalah kegiatan perencanaan dan perancangan kembali suat bangunan sehingga terjadi perubahan fisik tanpa merubah fungsinya baik melalui perluasan ataupun pemindahan lokasi. Redesain Rumah Sakit Umum Daerah Tidar Tipe B Kota Magelang dilaksanakan dengan tujuan untuk mendapatkan/ menentukan rumusan konsep perencanaan dan perancangan mendesain Rumah Sakit Umum Daerah Tidar Kota Magelang yang memenuhi kriteria masa depan. Dan sasaran dari perumusan adalah untuk mendapatkan konsep perencanaan dan perancangan Rumah Sakit Umum Daerah Tidar Kota Magelang

- Konsep perencanaan kembali pola tata ruang dan tata massa Rumah Sakit Umum Daerah Kota Magelang yang menunjukkan keteraturan, kemudahan dan kenyamanan sehingga dapat menunjang kelancaran yang diwadahi.

- Konsep batasan redesain area poli, Intalasi Gawat Darurat dan area parkir pada Rumah Sakit Umum Daerah Kota Magelang yang memenuhi kriteria masa depan.

- Konsep penampilan bangunan secara eksterior dan interior yang komunikatif dan dapat membuat pasien, kerabat pasien, seluruh user yang ada di rumah sakit merasa nyaman di Rumah Sakit Umum Daerah Tidar Kota Magelang.

\section{METODE}

Metode yang digunakan dalam merancang Redesain Rumah Sakit Umum Daerah Tidar Kota Magelang adalah dengan metode observasi dengan cara observasi lapangan dan media sosial. Kedua metode pengumpulan data dengan cara mengumpulkan data, kemudian dikompilasi dan dianalisis yang dirumuskan dalam konsep. Dan dalam metode perancangan terbagi dalam tiga tahap, yaitu programming, perencanaan dan perancangan. Berikut penjabaran dari tiga tahap yang dilakukan untuk merancang kembali bangunan Rumah Sakit Umum Daerah Tidar Kota Magelang: 
1. Programming: Bangunan Rumah Sakit Umum Daerah Tidar Kota Magelang akan memiliki banyak massa bangunan. Setiap massa bangunan perlu dijabarkan ke setiap kelompok unit berdasarkan aktifitas dalam kebutuhan ruang dan massa bangunan.

2. Perencanaan: Tiap Unit terdiri beberapa lantai bangunan. Dan pada setiap lantai dijabarkan dalam penzoningan berdasarkan kebutuhan.

3. Perancangan: Penerapan konsep yang telah direncanakan dituangkan kedalam desain 2D dan 3D.

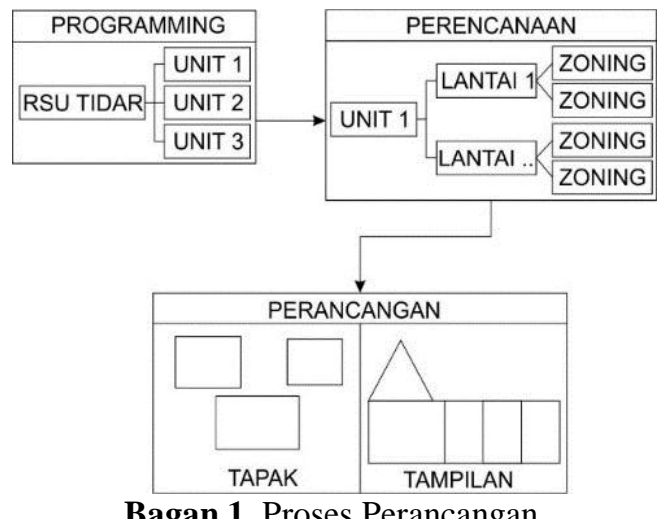

Bagan 1. Proses Perancangan.

\section{HASIL DAN PEMBAHASAN}

\section{a. Gambaran Umum RSUD Tidar Magelang}

Redesian Rumah Sakit Umum Daerah Tidar Kota Magelang tepatnya berada di Jalan Tidar Nomor 30A Kota Magelang, Kecamatan Magelang Tengah. Menurut RTRW 2011-2031 Kota Magelang wilayah ini memang dimanfaatkan untuk sektor kesehatan (lihat gambar 1).

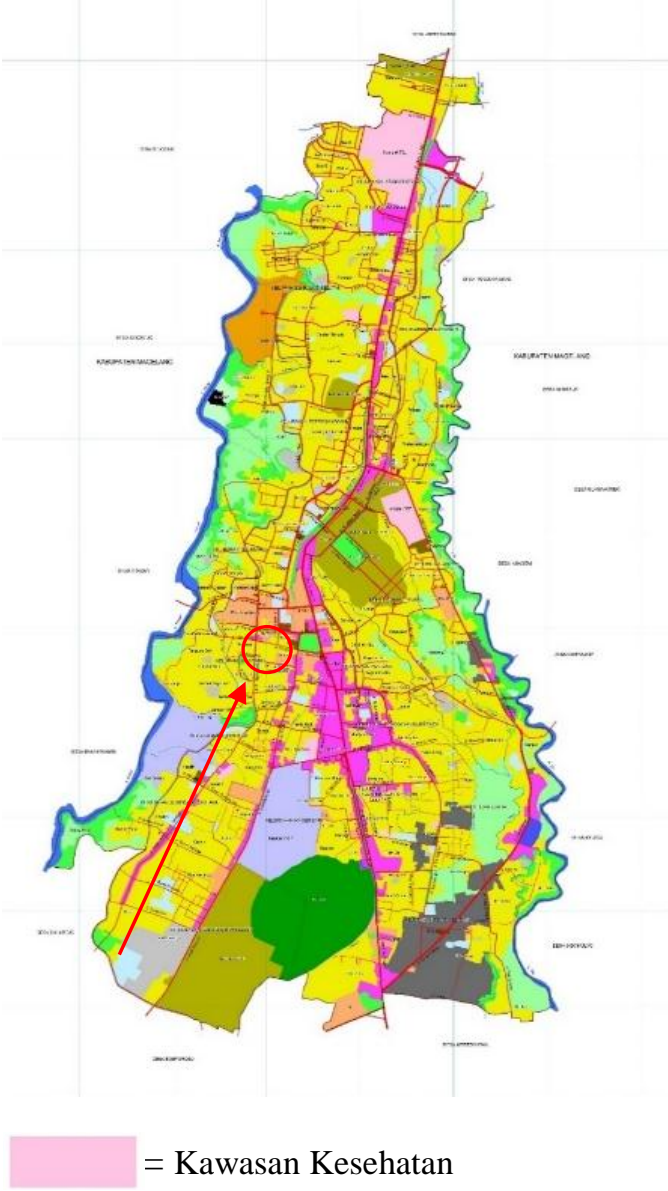

Gambar 1. RTRW Kota Magelang Sumber: BP2T Kota Magelang

Tapak tidak mengalami perubahan dalam redesain RSUD Tidar Kota Magelang karena tapak ini memenuhi kriteria tapak untuk bangunan kesehatan, yakni dekat dengan jalan utama, mudah dicapai, serta memiliki kontur yang datar.

Orientasi tapak mengarah ke selatan (arah jalan utama) dan ke timur. Hal ini dilakukan karena di sebelah selatan dari tapak merupakan jalan yang cukup ramai. Jalan tersebut adalah Jalan Tidar. Jalan Tidar ini meruapakan jalan satu arah dari timur ke barat yang merupakan pertemuan arus dari Jalan Pemuda dan Jalan Jend. Sudirman. Hal ini membuat Jalan Tidar menjadi jalan yang cocok untuk menjadi orientasi utama dari bangunan RSUD Tidar.

Pencahayaan matahari yang cukup karena area di sekitar tapak tidak ditemukan bangunan berlantai banyak. Rata-rata bangunan disekitar tapak hanya berlantai 1-3 lantai. Jadi bangunan 
RSU Tidar mendapat pencahayaan alami yang optimal dari semua sisi.

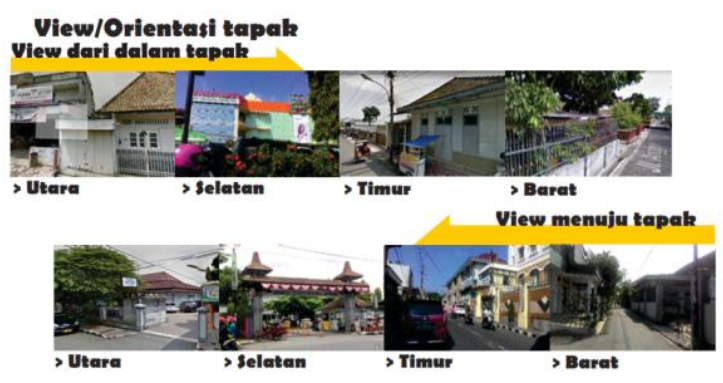

Gambar 2. Orientasi Tapak

Dari sebelah utara tapak merupakan bangunan komersial seperti bengkel, ruko dan rumah rumah warga. Sedangkan dari sebelah selatan yang menjadi point-of-interest bangunan RSUD Tidar berdekatan dengan Giant Supermarket dan UMM Magelang. Untuk di sisi barat tapak berdekatan dengan rumah warga dan SMK Wiyasa. Sedangkan di sebelah timur tapak berdekatan dengan GKI Pajajaran dan Pasar Tukangan yang selalu ramai dipagi hingga siang hari. (lihat gambar 2)

Dari sisi peruangan, terdapat beberapa ruang yang menjadi fokus permasalahan, antara lain: penataan kelompok ruang bedasarkan perbandingan preseden pada RS Pendidikan UNS dan Vincentius A Paulo (lihat tabel 1). Selanjutnya ruang-ruang yang lebih spesifik dibahas antara lain: area poliklinik, area IGD, area parkir dan area cagar budaya.

Tabel 1. Perbandingan Zonifikasi RS Pendidikan UNS dan Vincentius A Paulo

\begin{tabular}{|c|l|l|}
\hline Lantai & \multicolumn{1}{|c|}{$\begin{array}{c}\text { RS Pendidikan } \\
\text { UNS }\end{array}$} & \multicolumn{1}{|c|}{$\begin{array}{c}\text { Vincentius A } \\
\text { Paulo }\end{array}$} \\
\hline Basement & Area Servis & - \\
\hline I & $\begin{array}{l}\text { Area Servis, } \\
\text { Privat, Publik }\end{array}$ & $\begin{array}{l}\text { Area Servis, } \\
\text { Privat, Publik }\end{array}$ \\
\hline II & $\begin{array}{l}\text { Area Servis, } \\
\text { Privat, Publik }\end{array}$ & $\begin{array}{l}\text { Area Servis, } \\
\text { Privat, Publik }\end{array}$ \\
\hline III & $\begin{array}{l}\text { Area Servis, } \\
\text { Privat, Publik }\end{array}$ & $\begin{array}{l}\text { Area Servis, } \\
\text { Privat, Publik }\end{array}$ \\
\hline IV & $\begin{array}{l}\text { Area Servis, Area } \\
\text { Privat }\end{array}$ & $\begin{array}{l}\text { Area Servis, Area } \\
\text { Privat, }\end{array}$ \\
\hline V & $\begin{array}{l}\text { Area Servis, Area } \\
\text { Privat }\end{array}$ & - \\
\hline VI & $\begin{array}{l}\text { Area Servis, Area } \\
\text { Privat }\end{array}$ & - \\
\hline VII & $\begin{array}{l}\text { Area Servis, Area } \\
\text { Privat }\end{array}$ & - \\
\hline Roof & Area Servis & - \\
\hline
\end{tabular}

\section{b. Pengolahan Tapak}

Pengolahan tapak yang dilakukan untuk meredesain RSUD Tidar Kota Magelang adalah dengan melakukan zoning kelompok ruang untuk menjadikan kelompok ruang lebih tertata. Zoning ini dilakukan dengan mengelompokkan ruangan-ruangan menurut karakter ruang.

Zona tapak dibagi dibagi menjadi karakter zona secara horizontal dan zona vertikal. Pembagian zona horizontal yaitu zona bedasarkan tingkat risiko penularan penyakit yang terdiri dari risiko rendah hingga ke risiko tinggi, privasi kegiatan dari area publik hingga ke privat, zonasi bedasarkan pelayanan (medik dan perawatan, penunjang dan operasional, penunjang umum dan administrasi) dan secara vertikal bedasarkan hasil perbandingan antara preseden RS Pendidikan UNS Pabelan dan Vincentius A Poulo (lihat tabel 1).

Kesimpulan yang dilakukan terhadap zoning peruangan secara vetikal dan horizontal adalah sebagai berikut (lihat gambar 3)

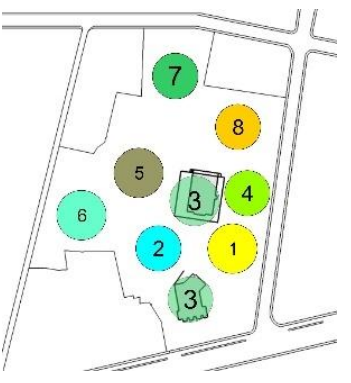

(a)
Keterangan:

1. IGD

2. Penerimaan

3. Administrasi

4. Bedah

5. IR. Inap

6. IR. Jalan

7. Servis (motel)

8. Servis (genset)

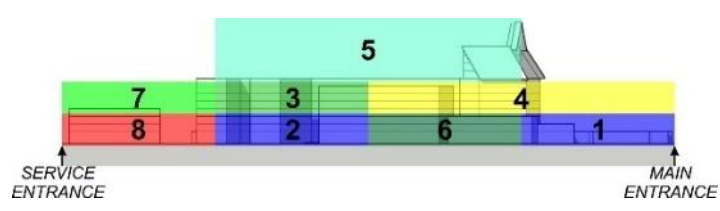

(b)

Gambar 3. Simpulan Zona secara (a)horizontal dan (b)vertikal

\section{c. Batasan Redesain}

Batasan redesain ini perlu dilakukan mengingat terbatasnya waktu dan kekompleksitas dalam mendesain. Dan dalam sub-poin ini dijelaskan keadaan sebelum terjadinya redesain. Terpilihnya area yang akan desain adalah pada area yang lebih gelap (lihat gambar 4) dengan pertimbangan adalah sebagai berikut: 


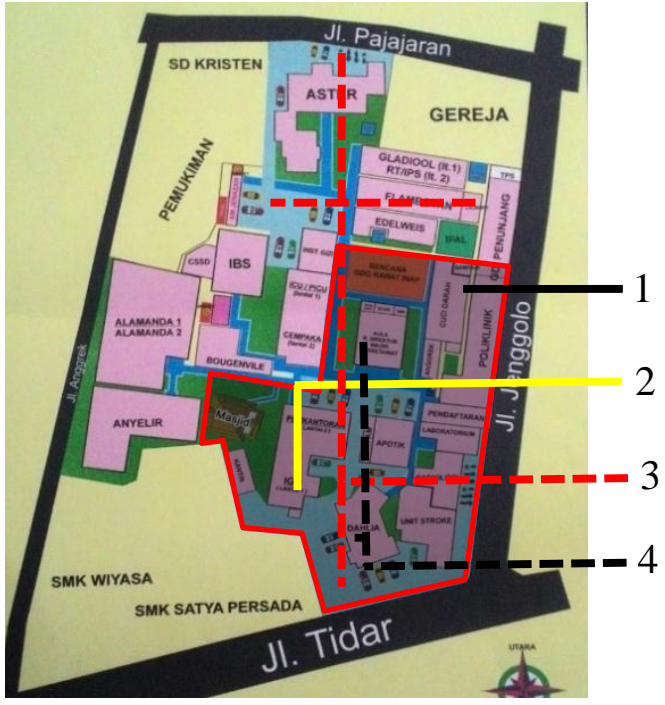

Gambar 4. Denah RSUD Tidar Kota Magelang Sumber: Bag. SarPras RSUD Tidar Kota Magelang, 2017

Keterangan:

\begin{tabular}{|l|l|l|l|}
\hline No & Ruang & No & Ruang \\
\hline 1 & Poliklinik & 3 & Area Parkir \\
\hline 2 & IGD & 4 & Cagar Budaya \\
\hline
\end{tabular}

\section{1) Area Poliklinik}

Area Poliklinik menurut Permenkes No.26 Tahun 2016 tentang persyaratan teknis dan prasarana rumah sakit (Instalasi Rawat) adalah merupakan fasilitas kesehatan yang wajib ada untuk Rumah Sakit Umum Tipe B yang mana letaknya haru mudah diakses dari pintu masuk utama rumah sakit dan memiliki akses yang mudah ke ruang rekam medis, ruang farmasi, ruang radiologi, dan ruang laboratorium. Ruang rawat jalan harus memiliki ruang tunggu dengan kapasitas yang memadai dan sesuai kajian kebutuhan pelayanan. Serta desain ruangan pemeriksaan pada ruang rawat jalan harus dapat menjamin privasi pasien.

Pada kenyataannya, ruang yang ada di Instalasi Rawat Jalan perlu untuk dikembangkan terutama untuk ruang pendaftaran yang mana selalu penuh dan ruang perawatan karena kecenderungan terjadi penambahan pasien setiap tahunnya (lihat gambar 5) dan terjadinya crowded disaat jam pendaftaran berlangsung (lihat gambar 6). Maka, perlu adanya pengembangan ruang pendaftaran sehingga tidak terjadi penumpukan pada area pendaftaran. (lihat gambar 7)

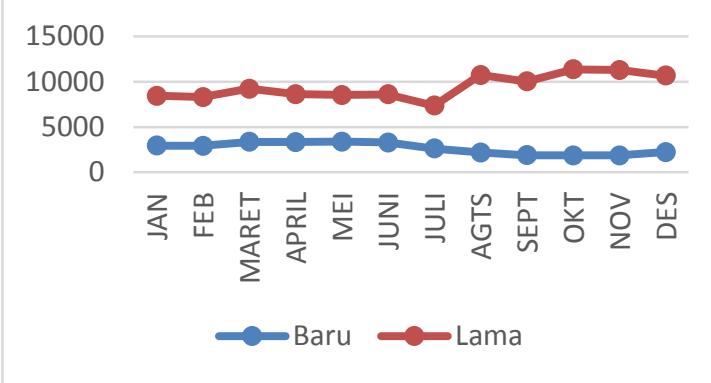

Gambar 5. Kunjungan Pasien Rawat Jalan RSUD Tidar Kota Magelang Tahun 2016

Sumber: RSUD Tidar Kota Magelang dalam Angka Tahun 2016

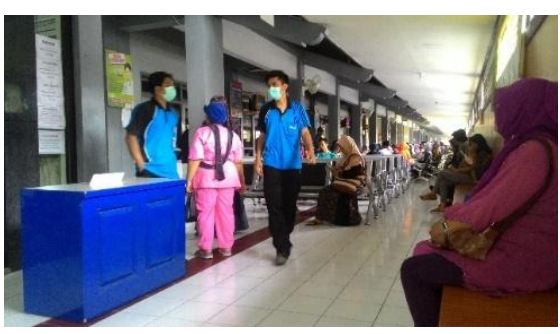

Gambar 6. Kondisi Pendaftaran Poliklinik

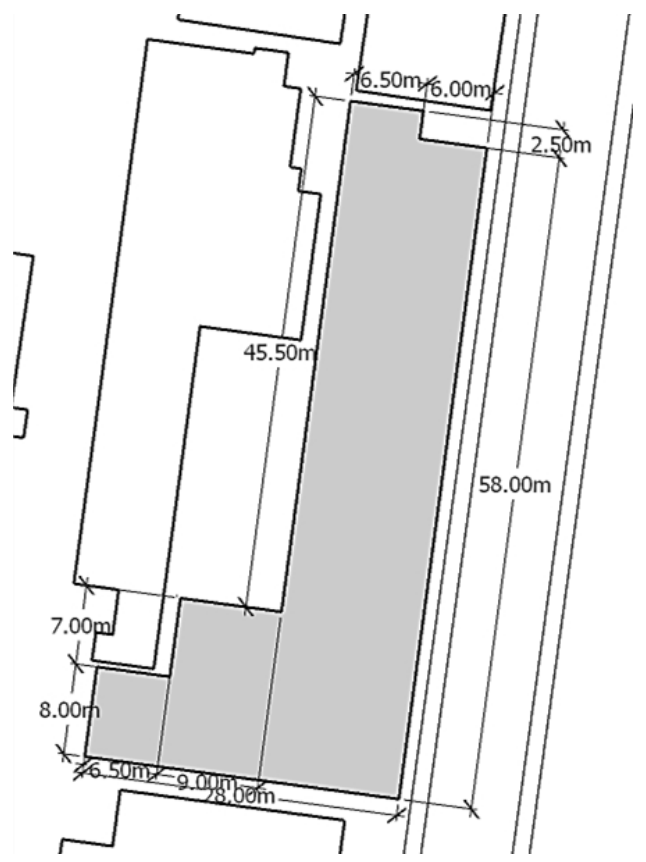

Gambar 7. Denah Area Poliklinik

Sirkulasi pasien dan petugas menjadi satu dan juga terlihat kolom-kolom bangunan yang menjorok ke luar, hal ini menyebabkan tidak dapat dipasangnya hand rail untuk membantu keseimbangan pasien terutama pasien usia lanjut saat melalui lorong pada area instalasi rawat jalan. (lihat gambar 8) 


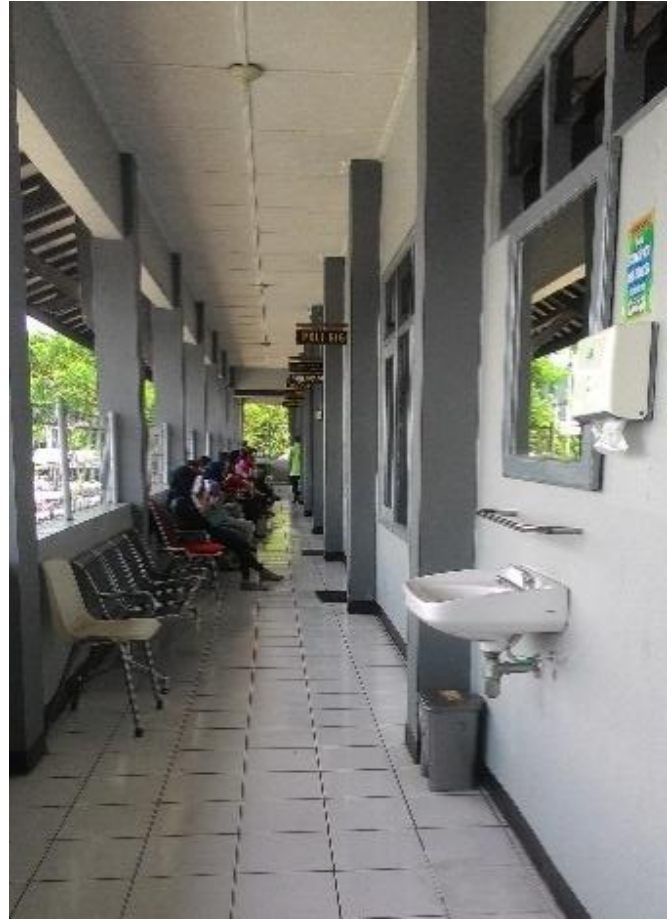

Gambar 8. Kondisi Sirkulasi IRJ RSUD Tidar

Maka dengan kasus yang ada, perlu dilakukan redesain terhadap sirkulasi pasien yang ada di poliklinik. Redesain dengan menambah hand rail dan meratakan dinding luar. (lihat gambar 9)

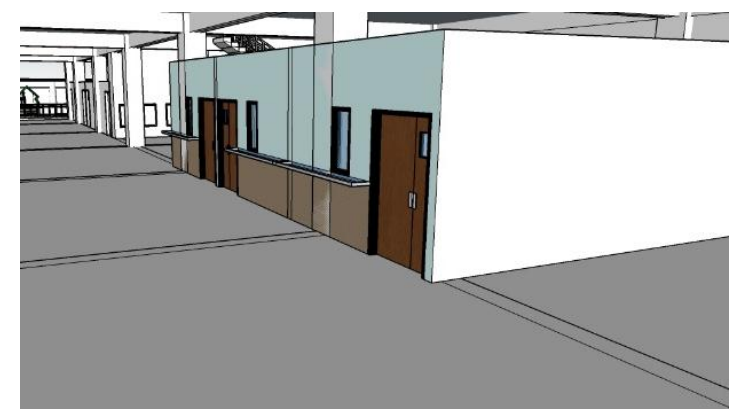

Gambar 9. Redesain Poliklinik

\section{2) Area IGD}

Area IGD menurut Permenkes no.24 tahun 2016 tentang persyaratan teknis dan prasarana rumah sakit (Instalasi Gawat Darurat) yang mana letak ruang gawat darurat harus memiliki akses langsung dari jalan raya dan tanpa hambatan. Letak ruang gawat darurat harus memiliki akses yang cepat dan mudah ke ruang operasi, ruang kebidanan, ruang radiologi, laboratorium, ruang farmasi dan bank darah rumah sakit. Akses masuk ruang gawat darurat harus dilengkapi dengan tanda penunjuk jalan, rambu-rambu, dan elemen pengarah sirkulasi yang jelas. Desain tata ruang gawat darurat harus dapat mendukung kecepatan pemberian pelayanan.

Namun, pelayanan IGD yang terjadi saat ini terdapat permasalahan yaitu drop-off yang masih perlu pengembangan. Drop-off yang tersedia hanya dapat menampung 1 kendaraan sehingga ketika kendaraan lain ingin melakukan drop-off di IGD harus menunggu kendaraan lain di depannya untuk segera meninggalkan area drop-off. Ditambah sukarnya kendaraan untuk bermanuver setelah meninggalkan area drop-off IGD yang mana saat bermanuver sisi jalan harus bersih dari kendaraan lain. (lihat gambar 10)

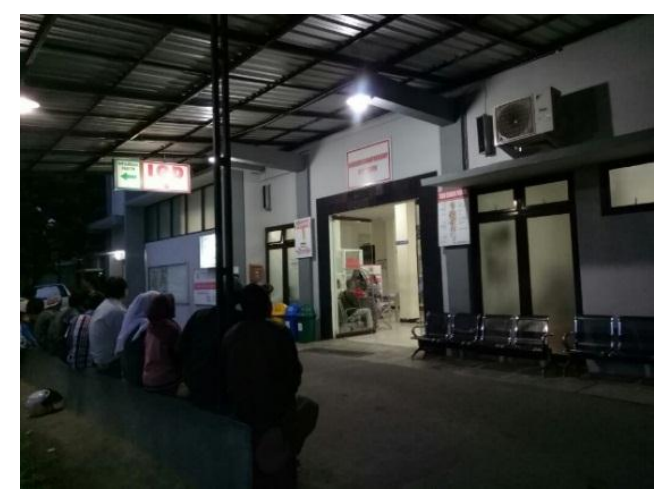

Gambar 10. Area Drop-off IGD RSUD Tidar Kota Magelang

Maka perlu adanya pengembangan pada area drop-off yang mana harus dapat diakses langsung dari main entrance dan pemisahan jalur masuk untuk ke area IGD dan rawat inap. Dan juga perlu adanya ruang penanganan bencana masal. Sedangkan untuk manajemen sudah baik.

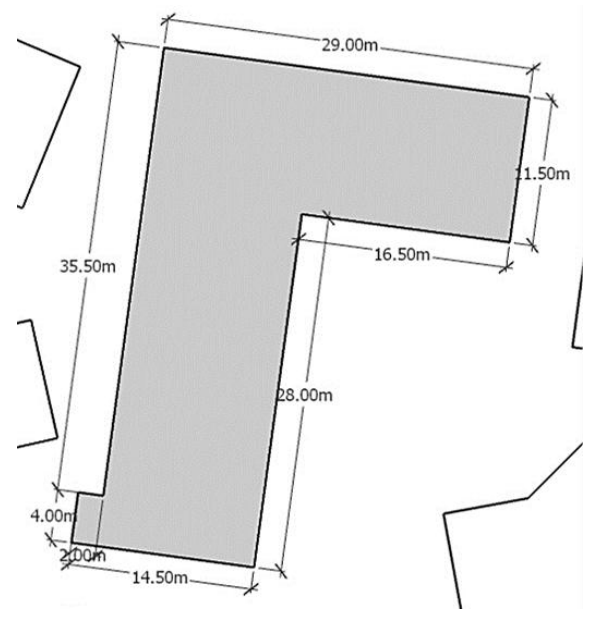

Gambar 11. Denah Area IGD 


\section{3) Area Parkir}

Untuk area parkir perlu adanya pengembangan area parkir karena adanya penambahan TT sehingga area parkir ikut bertambah untuk memenuhi kenyamanan user dalam Rumah Sakit Umum Daerah Tidar Kota Magelang.

Dan juga pengembangan jumlah TT yang diinginkan oleh pihak Rumah Sakit Umum Daerah Tidar Kota Magelang. Sedangkan kondisi sekarang area parkir yang terbatas di tambah dengan sedang dibangunnya Instalasi Rawat Inap 8 lantai. (lihat gambar 12)

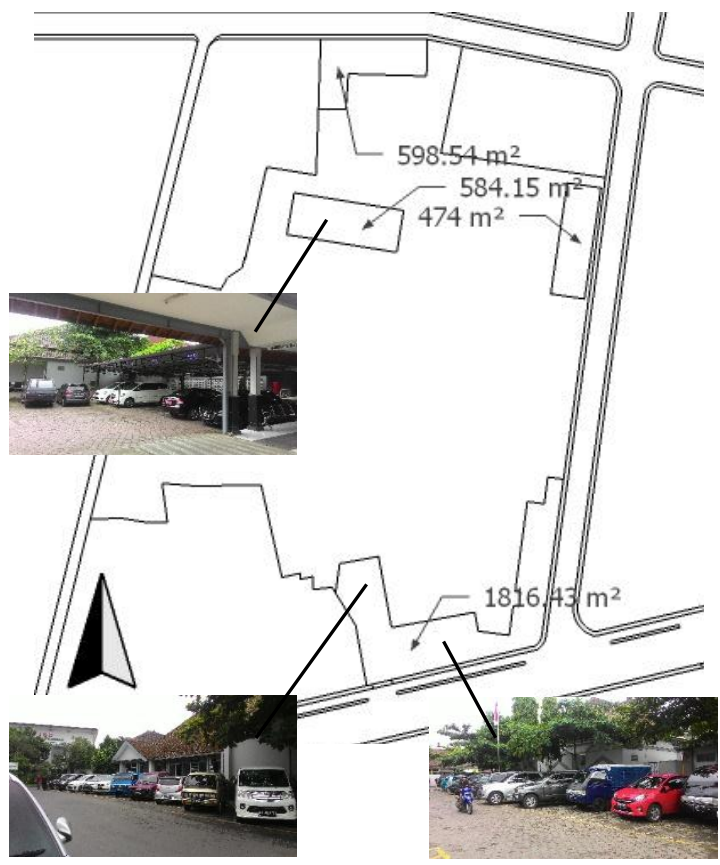

Gambar 12. Denah Area Parkir

Area parkir masih jauh dari standar yang dibutuhkan, karena: Kedepannya Rumah Sakit Umum Daerah Tidar Kota Magelang akan mampu menampung hingga $500 \mathrm{TT}$, jumlah TT $\times 60 \%=500 \times 0.6=300$ tempat parkir, atau kurang lebih $3600 \mathrm{~m}^{2}$.

\section{4) Area Cagar Budaya}

Area cagar budaya yang dimaksud adalah Ruang Bangsal Dahlia. Bangsal ini merupakan bangsal untuk usia anak-anak. Akan tetapi, bangunan ini akan masuk ke dalam bangunan cagar budaya tidak, masih belum menemukan titik temu. Hal ini terjadi karena masih banyak pertimbangan yang diupayakan dari pihak RSUD Tidar Kota Magelang dan dinas-dinas terkait. Namun untuk saat ini, kami berusaha untuk tetap menjaga bangunan yang saat ini menjadi bangunan bangsal Dahlia (Bangsal Anak) karena bangunan ini merupakan bangunan cikal berdirinya RSUD Tidar Kota Magelang. (lihat gambar 13)

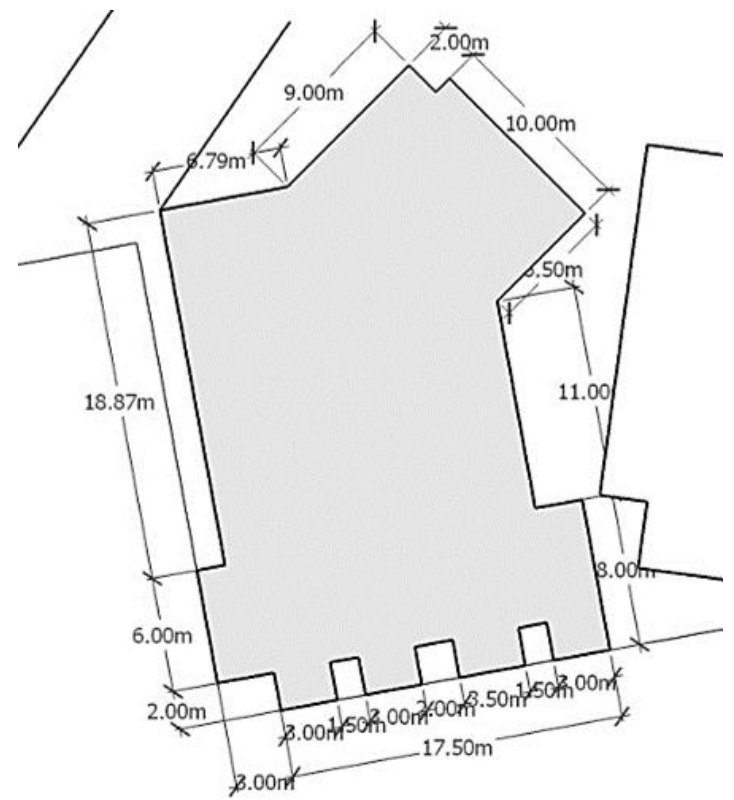

Gambar 13. Denah Cagar Budaya (sebagai Bangsal Dahlia)

\section{5) Instalasi Rawat Inap}

Instalasi Rawat Inap sebenarnya tidak menjadi prioritas utama dalam meredesain Rumah Sakit Umum Daerah Tidar Kota Magelang, karena kesesuaian dengan persyaratan. Berikut merupakan standar ruangan rawat inap.

Tabel 2. Kebutuhan minimal luas ruangan pada ruang rawat inap

\begin{tabular}{|l|l|l|}
\hline No & Nama Ruang & Luas (m2/TT) \\
\hline 1 & Ruang VIP & 18 \\
\hline 2 & Kelas I & 12 \\
\hline 3 & Kelas II & 10 \\
\hline 4 & Kelas III & 7.2 \\
\hline
\end{tabular}

Sumber: Pedoman Teknis Bangunan Rumah Sakit Ruang Rawat Inap, 2012.

Setelah melakukan analisis terhadap batasan redesain yang disepakati, maka akan didapat redesain terhadap bangunan:

\section{1) Area Poliklinik}

Sirkulasi dan ruang tunggu menjadi lebih luas sehingga menjadi lebih nyaman dan dapat menempatkan hand rail untuk membantu keseimbangan pasien saat melalui lorong pada area instalasi rawat jalan. Ditambah akses yang 
lebih mudah untuk pasien karena dapat langsung keluar pintu sebelah timur dan bertemu parkiran kendaraan roda dua maupun roda empat. Dan lebih mudah mencapai pusat ATM centre untuk memudahkan pembayaran.

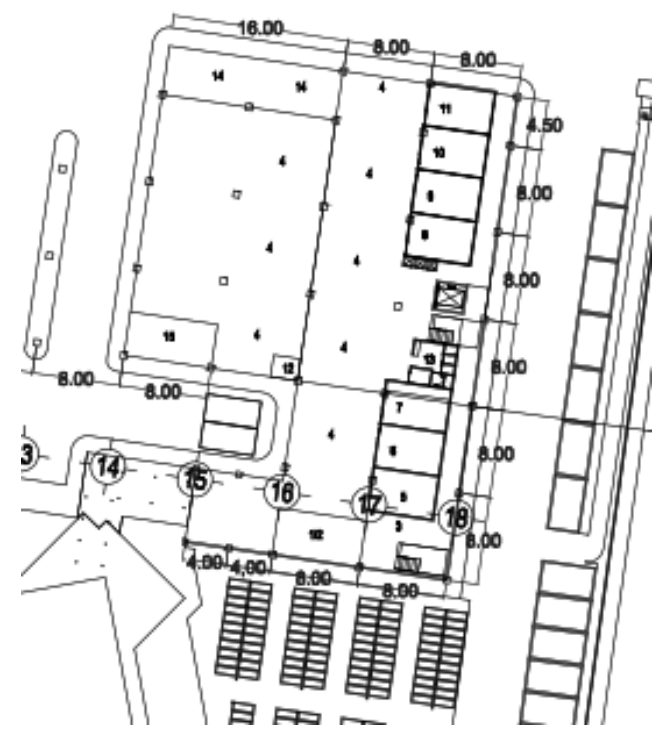

Gambar 14. Denah Hasil Redesain Instalasi Rawat Jalan

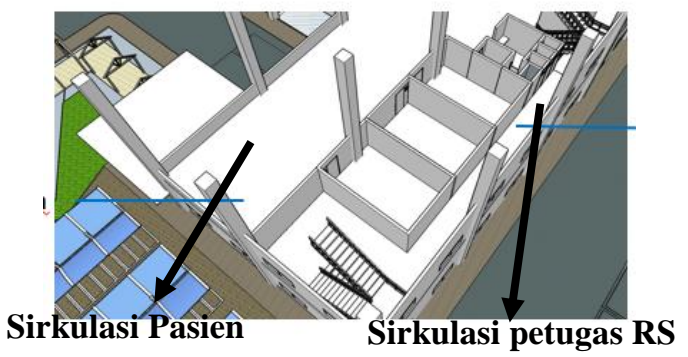

Gambar 15. Perspektif Sirkulasi IRJ

Pemisahan jalur sirkulasi pasien dan sirkulasi petugas RS sesuai dengan pedoman rumah sakit tipe B tahun 2012 untuk mengurangi penyebaran penyakit dan kepadatan sirkulasi.

\section{2) Area IGD}

Area drop-off pada hasil redesain dapat menampung lebih dari empat mobil sekaligus dan drop-off ini sudah terpisah dengan area yang menuju area rawat inap maupun rawat jalan. Kemudian ditambah dengan lingkaran (lihat gambar 16) untuk memudahkan manuver kendaraan karena letaknya disudut dan menambah estetika RSUD Tidar Kota Magelang karena dapat digunakan sebagai air mancur dan skluptur.

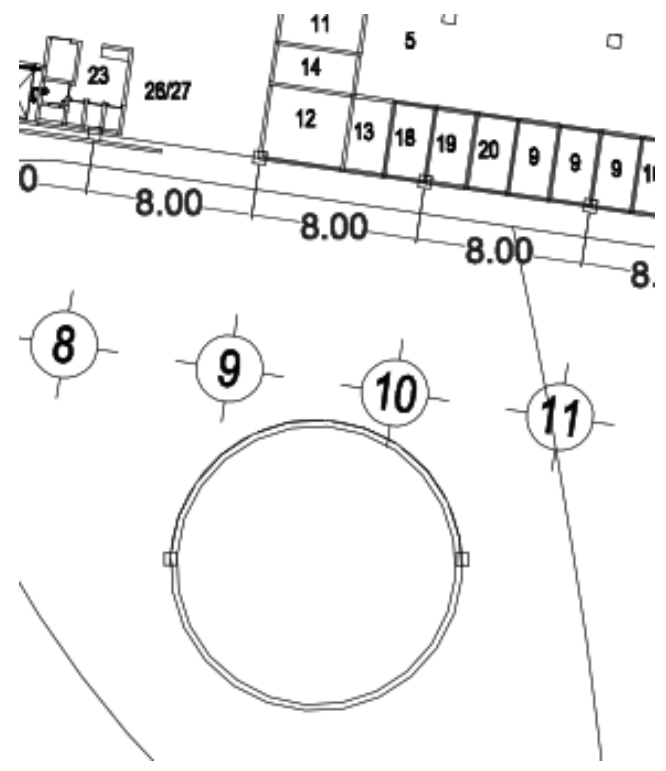

Gambar 16. Denah drop-off IGD

3) Area Parkir.

Sedangkan untuk perlakuan studi kasus area parkir pada Redesain Rumah Sakit Umum Daerah Tidar Kota Magelang diletakkan pada area basemen dan beberapa terkoneksi menuju loby utama dan lobi pada area rawat inap sehingga memudahkan dalam menjangkau titik kumpul yang penting. (lihat gambar 17)

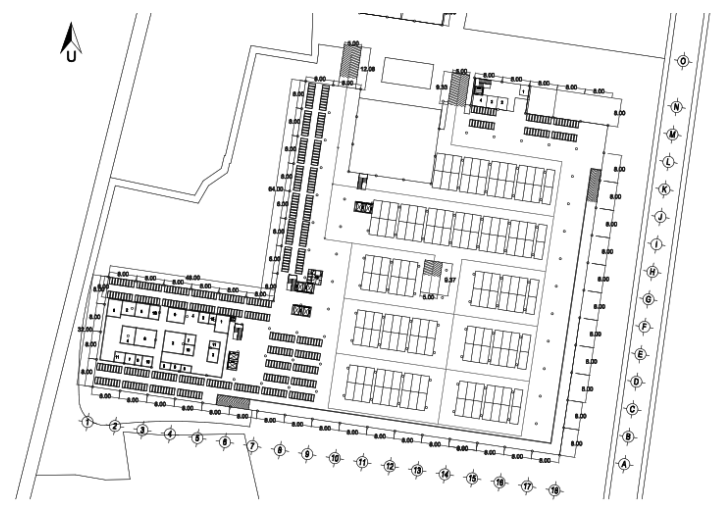

Gambar 17. Denah Parkir IGD

4) Area Cagar Budaya

Untuk area cagar budaya yang dimaksud akan dialihfungsikan sebagai area drop-off menuju Instalasi Rawat Jalan tanpa mengubah bentuk bangunan.

5) Instalasi Rawat Inap

Setelah melakukan analisis untuk area Instalasi Rawat Inap diperoleh hasil desain seperti berikut: 


\section{- $\quad$ Ruang Inap Kelas III}

Ruang Inap Kelas III terdiri dari 5 Tempat tidur dalam satu ruang dilengkapi dengan satu kursi untuk penunggu pasien (lihat gambar 18).

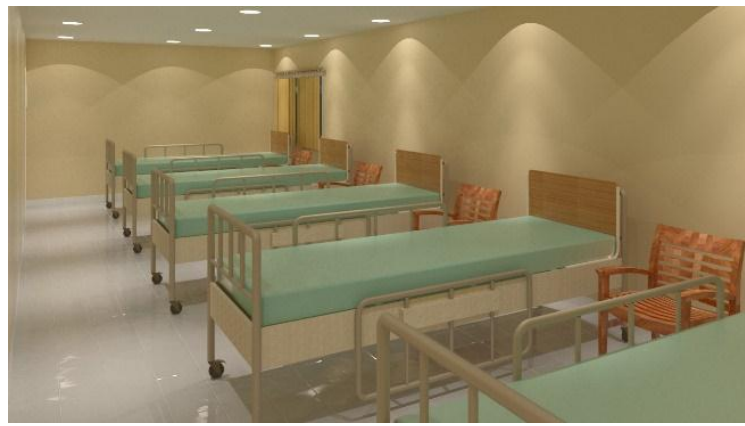

Gambar 18. Rawat Inap Kelas III

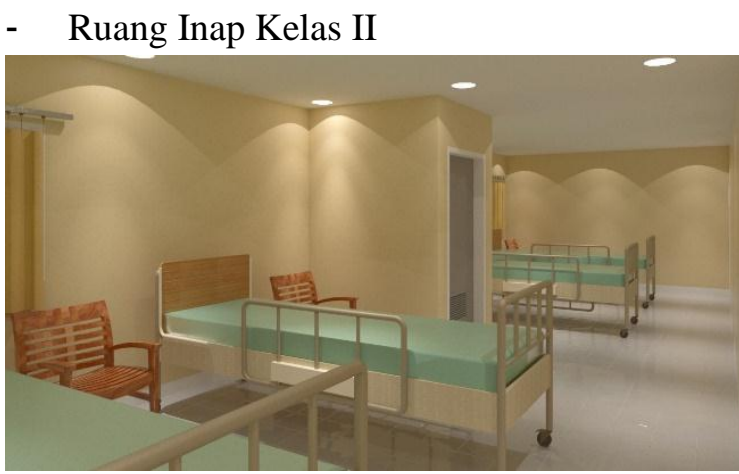

Gambar 19. Rawat Inap Kelas II

Ruang Rawat Inap Kelas II yang terdiri dari 4 TT dilengkapi dengan kursi untuk penunggu pasien. Perbedaan antara kelas III dan kelas II adalah Rawat Inap Kelas II terdapat toilet didalam ruangnya sehingga pasien tidak perlu keluar ruangan untuk menuju toilet (lihat gambar 19).

\section{- Ruang Inap Kelas I}

Ruang Inap Kelas I terdiri dari 2TT untuk setiap kamarnya. Di setiap tempat tidurnya disediakan kipas angin untuk tiap tempat tidurnya dan satu kabinet untuk satu kamar. Tersedia satu kamar mandi untuk tiap 2TT (lihat gambar 20)

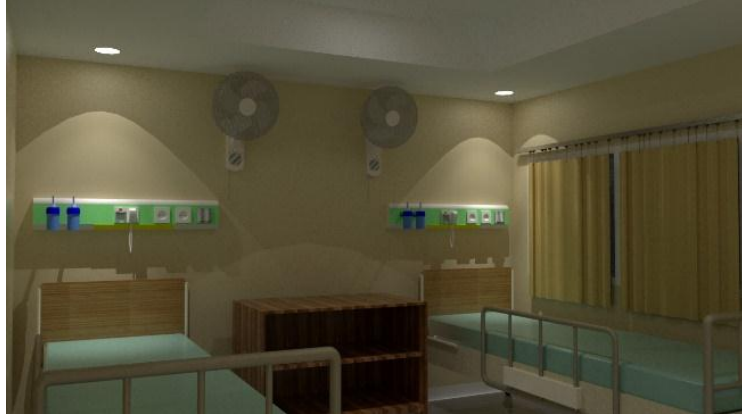

Gambar 20. Rawat Inap Kelas I

\section{- $\quad$ Ruang Inap Kelas VIP}

Untuk ruang rawat inap kelas VIP disediakan 1TT untuk setiap kamarnya. Fasilitas yang tersedia seperti AC, TV, sofa dan kabinet serta kamar mandi (lihat gambar 20).

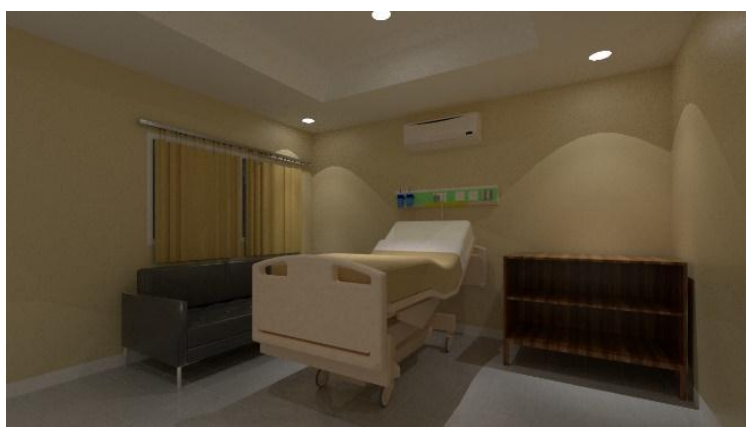

Gambar 21. Rawat Inap Kelas VIP

\section{KESIMPULAN}

Rumah Sakit Umum Daerah Tidar Kota Magelang akan terus berkembang dalam memberikan pelayanan professional sebagai manifestasi pengabdiannya kepada masyarakat Kota Magelang dan sekitarnya.

Pedoman Rumah Sakit Umum Tipe B tahun 2012 menjadi acuan dalam mendesain Redesain Rumah Sakit Umum Daerah Tidar Tipe B Kota Magelang sehingga dapat menambah kenyamanan dan mempercepat penyembuhan terhadap pasien yang berobat ke RSUD Tidar Kota Magelang. Penerapan kriteria perancangan yang diterapkan pada:

a. Pengolahan Tapak

Kriteria perancangan yang diterapkan pada tapak adalah kriteria kemudahan pencapaian tapak; kriteria tingkat kepadatan lalu lintas yang mengacu pada main dan site entrance; kriteria pencahayaan dan pembagian zona untuk 
menyesuaikan dengan kebutuhan seperti rawat inap, rawat jalan dan bangunan lainnya.

b. Batasan Redesain

Penerapan kriteria perancangan bedasarkan batasan redesain untuk memudahkan kami dalam Redesain Rumah Sakit Umum Daerah Tidar Kota Magelang. Batasan Redesain terbatas pada area IGD, rawat jalan dan area parkir.

c. Hasil Redesain

Hasil redesain menurut analisis yang telah dilakukan maka diperoleh area rawat jalan yang memisahkan area sirkulasi petugas RS dan pasien. Untuk area IGD area drop-off lebih banyak menampung kendaraan dan sirkulasi yang terpisah dengan kendaraan yang menuju area rawat inap dan area rawat jalan. Untuk area parkir diletakkan pada basemen rumah sakit, namun tetap dimudahkan akses terhadap bangunan rawat inap dan loby utama sehingga mempermudah pengunjung dan petugas RS menjangkau semua area dalam RS.

\section{REFERENSI}

Atik Prihatiningrum. (2014). Rumah Sakit Stroke di Kota Surakarta sebagai Lingkungan Penyembuh melalui Pendekatan Arsitektur Berkelanjutan. Diambil 12 Januari 2018, dari https://jurnal.uns.ac.id/Arsitektura/article /view/15706/12640

Kemenkes RI. (2010). Klasifikasi Rumah Sakit/340/Menkes/PER/III/2010. Jakarta

Kemenkes RI. (2012) Pedoman Penyusunan Rencana Induk (master Plan) Rumah Sakit. Jakarta.

Kemenkes RI. (2012). Pedoman Teknis Bangunan Rumah Sakit Kelas B. Jakarta.

Peraturan Daerah Kota Magelang Nomor 4 Tahun 2012 Tentang Rencana Tata Ruang Wilayah Kota Magelang Tahun 2011 2031. (n.d.). Diambil 19 Mei 2017, dari http://bappeda.magelangkota.go.id/index. php/rancangan-tata-ruang/78-perda-kotamagelang- no-4-tahun-2012-tentangrencana-tata-ruang-wilayah-kotamagelang- tahun-2011-2031
WHO | Hospitals. (n.d.). Diambil 3 April 2017, dari http://www.who.int/hospitals/en/ 